\title{
Level of self esteem in men and women north zone Badminton players
}

\author{
Zamirullah khan* Anwar Ali* \& Naseem Ahmed** \\ *Deptt. of Physical Education A M U Aligarh U.P. India ** Mumtaz P G College Lucknow, U. P. India
}

\begin{abstract}
The purpose of this study was to find out self- esteem levels of north zone men and women badminton players. The tournament was held at Jamia Millia Islamia University 2013-2014. The sample of the present study comprised of 50 (25 men and 25 Women) badminton players. The questionnaire of self esteem by Rosenberg (1965) was used in this study. The result of the study showed that men players had much more high self esteem than their counter part.
\end{abstract}

\section{Introduction}

Self esteem is one of the dimensions of personality which helps in knowing the personal satisfaction and effective functioning whether people's self esteem is high or low has a tremendous impact on their ability to derive joy and satisfaction from life. Self-esteem has become a household word. People high in self-esteem claim to be more likable and attractive, to have better relationships, and to make better impressions on others than people with low self esteem.

Self esteem is the regard that one hold for oneself. It is important to know that self-esteem can be gained at any time in the life. Self-esteem is a state of mind. Self esteem is one dimension of self concept and refers specifically to our self evaluations. It is also termed as self worth and is understood as generalized feelings of adequacy or inadequacy on the part of the individual.

Cooper smith (1981) defined self esteem as a positive or negative attitude and value by which a person view the self image and the evaluation or judgment he makes about it from the person's self esteem.

People who value their competence and worth in terms of positive terms are said to have high self esteem and those whose self evaluations are poor described as having low self esteem Pestonjee, (1995).

Asci (1999), King and colleagues (2000), self-esteem is important from such points of view as the individual's gaining his autonomy, having a life full of satisfaction, carrying out activities directed at a goal, establishing healthy and perpetual relations, having a high level of the ability to adaptation, developing value systems, being successful and the ability to plan the future.

Yorukoglu, (1988) self-esteem is a psychological state that arises from the affirmation of the concept of ego that a person attains as a result of adopting himself and having a high opinion about himself, his self confidence and self esteem. Such positive psychological traits as self-esteem, optimism, will be successful, not giving in the difficult are observed in individuals with a high level of self-esteem. Individuals with a low level of self-esteem, on the contrary, has a low level of self-esteem, they give away to despair easily and shortly they are more down to developed negative psychological symptoms.

Kassin (1998), has stated that the individuals with a low level of self-esteem have exhibited such traits as waiting for the failure, nervousness, showing a low level of effort and that they may neglect important aspects of life and may blame themselves as valueless and untalented when they are unsuccessful.

Sample

\section{Methodology}

Data was collected from North zone badminton university tournament held at Jamia Milia Islamia University. The sample consisted of 50 (25 men and 25 Women) badminton players. The age of the subjects ranged from 18 to 28 years.

\section{Tools used}

The researcher used self esteem questionnaire developed by Dr. Rosenberg, M. (1965). The scale consists of 10 items related to the self esteem. Four alternatives characterized by the nature of the statements from which a respondent has to choose any one.

\section{Scoring}

The scale is of a ten item scale with items answered on a four point scale from strongly agrees, agree, disagree and strongly disagree. $\mathrm{SA}=4, \mathrm{~A}=3, \mathrm{D}=2, \mathrm{SD}=1$. Items with an asterisk are reverse scored, that is, 
$\mathrm{SA}=1, \mathrm{~A}=2, \mathrm{D}=3, \mathrm{SD}=4$. Sum the scores for the 10 items. The higher score, the higher the self esteem. The following interpretation of the score denotes the levels of self esteem.

\begin{tabular}{|l|l|}
\hline Scores & Degree of Satisfaction \\
\hline 35 or above & High self esteem \\
\hline $25-35$ & Medium self esteem \\
\hline Scores below 25-15 & Low self esteem \\
\hline
\end{tabular}

III. Results:

\begin{tabular}{|c|c|c|c|c|c|c|c|}
\hline \multirow{3}{*}{ Gender } & \multicolumn{4}{|c|}{ Levels of Self Esteem } & \multirow{2}{*}{\multicolumn{2}{|c|}{ Low Self Esteem }} & \multirow{3}{*}{ Total } \\
\hline & \multicolumn{2}{|c|}{ High Self Esteem } & \multicolumn{2}{|c|}{ Medium Self Esteem } & & & \\
\hline & $\mathbf{N}$ & $\begin{array}{l}\text { Scoring of the } \\
\text { Players }\end{array}$ & $\mathbf{N}$ & $\begin{array}{l}\text { Scoring of the } \\
\text { Players }\end{array}$ & $\mathbf{N}$ & $\begin{array}{l}\text { Scoring of the } \\
\text { Players }\end{array}$ & \\
\hline Men & 12 & $48 \%$ & 8 & $32 \%$ & 5 & $20 \%$ & 25 \\
\hline Women & 9 & $36 \%$ & 13 & $52 \%$ & 3 & $12 \%$ & 25 \\
\hline
\end{tabular}

From the table it is evident that most of the men badminton players showing high self esteem as compared to women badminton players.

The above table showed that 12 i.e.48\% men badminton players scored high self esteem as compared to women 9 i.e. $36 \%$ badminton players out of 25 . On the other hand 8 i.e. $32 \%$ men players as compared to 13 i.e. $52 \%$ women showing medium self esteem and 5 i.e. $20 \%$ men players and 3 i.e. $12 \%$ women players scored low self esteem.

\section{Discussion}

The results obtained from the data showed that men badminton players scored higher self esteem scale as compared to women badminton players.

Men badminton players scored higher as compared to their counterpart, it might have been due to Involvement of 10 players (Subjects in the sample) who reached till the final in the men section.

Women players have a lower self-esteem than men players which is also supported by the Marcotte, Fortin, Potvin, \& Papillion, (2002), who observed that men have high self esteem as compared to women players.

Result in this study is also proven by Baumeister (2003), who in his research work proved that men badminton players had high self esteem in comparison to women badminton players

\section{Conclusions}

Men badminton players have high self esteem, it means they are confident and feel good about themselves, which is helpful to perform well in the competition. They have more energy for working hard to take care because of high self esteem.

\section{Reference}

[1]. Coopersmit, K., 1981. Discussion of some variables effecting attitudes of workers, Indian Journal of Psychology, 5 (1), 78-81.

[2]. Baumeister, R. F., Campbell, J. D., Krueger, J. I., \& Vohs, K. D. (2003). Does high self esteem cause better performance, interpersonal success, happiness, or healthier esteem lifestyles? Psychological Science in the Public Interest, 4, 1-44.

[3]. Yorukoglu A. (1988) Education of youth mental health and mental problems.

[4]. Kassin, S., (1998). Psychology, Second Edition, New Jersey: Prentice Hall.

[5]. Martens R. (1987) Coaches Guide to Sport Psychology Illinois, President Human Kinetics Publishers, 5-8.

[6]. Muthu, V. Jayanthi and D. Sakthigananave. (2011). An evaluation of the self-esteem of women sports participant in various games. International Multidisciplinary Research Journal 2011, 1, 01-04.

[7]. Pestonjee D.M., (1995). A study on the job areas of job satisfaction in relation to involvement and participation. International Multidisciplinary Research Journal 2011, 5(1), 67-69.

[8]. Marcotte, D., Fortin, L., Potvin, P., \& Myra Papillion (2002). Gender Differences in Depressive Symptoms during Adolescence: Role of Gender-Typed Characteristics, Self-Esteem, body image, and Pubertal status. Journal of emotional \& Behavioral Disorders, 10 (1), 29-43. 